\title{
The effectiveness of self-creation in
} improving job quality of social workers dealing with extracurricular school activities groups

\section{Hanaa Aref Ahmed Mohamed (PhD)}

Assistant Professor, Group Work Department

Faculty of Social Work- Aswan University 


\section{Abstract}

This study aimed to determine the effective role of self-creation in improving job quality of social workers dealing with extracurricular school activities groups. This study is one of the descriptive studies that use the comprehensive social survey of (99) social workers by using questionnaire during May 2019. The results of this study proved that there is a statistically significant relationship between the demographic variables (gender, age, marital status, academic qualification, and years of experience) and the level of selfefficiency in the creative thinking (fluency, flexibility, originality, and details). As a result, these lead to improve job quality of social workers dealing with extra-curricular school activities group. There is a statistically significant relationship between the demographic variables and level of self-efficiency in the creative performance of social workers (education for creativity, preservation of creative personality, communication and promotion of creativity).School social workers which working in educational fields can benefit by make use of this study results at primary and secondary year education in Egypt.

Keywords: effectiveness of self-creation quality of work, job quality, extra-curricular school activities groups, preparatory year students.

\section{Introduction}

The national association of social workers (NASW) has identified important guidelines for the delivery of social work services in schools, including standards for practice, professional preparation and development, and administrative structure and support. These guidelines are set forth in the (NASW) standards for school social work services, which were adopted in 1978 and revised in 1992 and again in 2002 (Openshaw,2008)

School social work is a distinct field of practice within the social work profession that primarily aims to support student learning and psycho-social functioning in educational settings. School social workers adopt a diverse set of roles and tasks in schools, including direct work with students and families, consultation with school staff, and facilitation of linkage between school and community resources (Stone 2015). 
The significant of this study is the importance of education field in social work, in general, and the way in which social group works in particular. Social group work method is one of the social work methods, which are applied in educational field and depending on the group worker who works with different school groups. Those groups enrich school life and make the school as educational institution which students get an experiences, human values, and skills. The students also learn democratic behavior and practice. It in order to get responsibility towards themselves, their school and their society (AlJundi , 2004, p. 287). Nowadays a vast variety of extracurricular activities are being offered in schools, colleges and universities. These extracurricular activities may include sports, debates, essay writing, drama or theatre, different clubs and student councils (Najum, et al, p.2).

Participation in out-of-school activities help develops students' brain contributing to better mental health. It also helps them fortify their academic performance for a long period. Extracurricular activities also reduce behavioral and disciplinary problems.

Extracurricular activities is also a form of education that being taught outside of the classroom. Through extra-curricular activities, the students will be educated in the form of spiritual, leadership, teamwork as well as self-confidence. Participation in these activities will provide the essential skills provided in these activities as well as fostering a healthy lifestyle. Extracurricular activities can strengthen the interaction between the students and at the same time promoting integration between the races as well as nurturing decencies, independencies, hard work, disciplined and obedient to the law which develops the students into becoming a useful citizen (Manchaa\&Ahmad,2016,p.774). Therefore, co-curricular activities are capable to improve social skill among students which will also help them in the future career prospect.

Therefore, co-curricular activities are closely related with the development of social skills to develop human capital that are able to enhance the future of a country. Hence, each activity conducted has to be suitable with their level of thinking to ensure they are more matured and responsible toward their future endeavors. This is because, in order to produce a responsible and mature individual, not only formal education that need to be equipped but also out-of- 
classroom learning via beneficial activities so that the students will not easily bored, the usage of leisure time can develop the skill, creative, innovative, ethics as well as high moral integrities to face the real world challenge after completing their school education (Daley\&Leahy,2003). Participation in extracurricular activities provide students with greater opportunities to interact with people outside their current social circle thus contributing to increased friendship and social confidence development. Participation in these activities promotes maturity and self-discipline in youngsters.

The preparatory years consider as the stage of early adolescence, which extends from the age of twelve years to fifteen. It is a stage of conflict between childhood and growth, so students in this stage in a struggle for independence and sense of self. Each of them reveals their role in the school community. As well as their role in their society (Abdel Radi , 2016, p.7). In addition, the preparatory years students are the most important human resources. Therefore, the majority of contemporary [trends in the social sciences and humanities are interested in studying the status of students their attitudes, values and roles in society.

The importance of extra-curricular activities in the preparatory school, and its educational role in the fact that this stage is the most important and most dangerous educational stages experienced by students, it is the stage of leaving childhood, the beginning of being adult, and the formation of independent self, which have needs and requirements for proper growth. The satisfaction of such needs necessary for the child's life in general.

After school extracurricular activities have long been recognized for contributing many ways to the enhanced school experience as well as to the increased social skills of students. Besides creating a school culture and promoting school spirit, extracurricular activities [have been found to have a relationship with students' academic performance development of responsibility discovering their abilities and interest, self-discipline and leadership skill (Adeyemo, 2010, p.p.11-117).

The development of creativity and innovation is considered as one of the most important topics of interest to the world today through the world's race towards control, power and knowledge. Therefore, researchers and scientists in various scientific fields are interested in 
this topic, these scientific fields like psychology, education, industry, media, .etc. (Suleiman, 1999 , p.166). Creativity, the development of novel and useful ideas, is important in today's society. Employees in different occupations are required to solve problems creatively, and to contribute to their employer's success by contributing suggestions on how to enhance efficiency and save costs. An individual characteristic that promotes creative outcomes is creative self- efficacy, the belief that one is able to develop novel and useful ideas (Tierney \& Farmer, 2002, p.p.437-438).

Creative self-efficacy has been linked to a range of favorable outcomes including the development and implementation of ideas (Ohly, 2017, p.126).

Bandura (2007) believes that the self-efficiency is the perceived procedural ability that is not related to what the individual has but related to what he can do whatever the surrounding circumstances. So the individual has not asked about his abilities level, but about his belief of the confidence to do the required activities in light of position requirements. So, the individuals' evaluation to their self-efficiency reflects the difficulty level that they think, they will face (Bandura , ,2007,P. 641).

Abbott, 2010, indicates that there are two main domains of creative self-efficacy; the first domain is self-efficacy in creative thinking, where it represents the extent of thinking-efficacy in the internal mental case, and expresses the creative thinking skills, that including: fluency, flexibility, detail, and originality .Where individual could produce new ideas suitable for the position. The second domain is self-efficacy in creative performance, which represents in the external social case, such as: expressing creativity through individual's internal and external features that interact together through creative performance such as: motivation, personal features, mood, social context, and ...etc.

Following up on kelley's theory, it is important to find out whether creative self-efficacy is related to creative output. If a significant relationship can be found, it means that a person can become more creative by enhancing their creative self-efficacy. As there is a lack of empirical research about the relation between self-efficacy and creative performance; it should be interesting to specifically analyze the link between the variables, creative self-efficacy and creative 
performance in a creative task, which is not related to a specific knowledge area (Brockhus et Al, 2014, P.438). The profession seeks to adopt modernization methods in order to achieve high quality in the quality of professional performance of social workers (NASW, 1990).

The social worker in the school field has many responsibilities, as assisting students in academic achievement, solving the problems they face, satisfying their various needs, and helping them to create right social relations with each other. In order to achieve the professional performance of the social worker in an effective and efficient way in the school, and make them able to achieve this responsibility. They must be familiar with the knowledge, professional and skill aspects in this area (Ahmed el al, 1999, p.28). A group worker is playing an important role in working with societies; group worker represents the institution in which he or she works in .The ability of social worker to influence the group is due to the degree of self-esteem and professional development (Hassan, 2015, p. 185).

The process of assistance and successful professional practice of social workers depends on of his understanding of the basics, principles and skills of the method when applied during his work. Therefore, there is a need to continuously search for several new ways to refine his experience and skills as a basis for continuous professional preparation and to provide him with the knowledge, skills and contemporary trends of professional work, so that he will be able to practice his work as efficiently and well as possible ( Shehata, 2012, p. 3699).

Accordingly, concern of the quality of the job life of social workers is considered as one of the priorities for development and modernization in the social services job, especially in the field of providing high-quality social services in institutions, lack of quality through time will undoubtedly affect the level of services provided. The insufficiency facing social workers is a challenge in the ineffectiveness of the service provided, the needs must be taken into consideration when addressing the deficiencies in view of the roles and responsibilities in which the employees carry out these responsibilities assigned to them in the desired manner (Maray, 2005, p.549). Despite traditional practice of social group work in the educational field in Egypt for a long time and despite the increase of the number of social workers in Egyptian schools, there is a clear 
shortage in job quality of social workers while dealing with extracurricular activities groups. This work requires the activation of creative self-efficiency to improve quality of job performance.

Ibrahim's Study (1992) emphasized the importance of conducting further studies on social performance of social workers working in all fields to address problems resulting from inadequate gob performance. Abulnasr's Study (1999) focused on the professional development of social workers in educational field and aimed to identify methods of professional self-development. The study indicated that the social workers use the means of professional self-development are moderate and the use of these means are low. Other studies in the twenty-first century also indicated that these constraints based on some social workers' point of view Abdul Hameed's Study (2003) confirmed that the job performance of social workers needs to be continuously improved and developed. Salim's Study (2011) pointed that social workers are facing many difficulties while practicing extra-curricular activities. From the social workers' point of view, these difficulties include: lack of resources and possibilities for extra-curricular activities, and lack of places dedicated to extra-curricular activities. These difficulties prevent the achievement of extra-curricular activity programs objectives in the view of a [comprehensive educational evaluation. Therefore, the specialist must decrease difficulties to activate extra-curricular activities .Al-Ghamdi's Study (2017), aimed to identify the difficulties of use the student guide for extra-curricular activities to develop social skills for primary school students, and identify the role of social worker to reduce obstacles that prevent the use of extra-curricular activities in developing social skills of the students, the activation of extra-curricular activities reflects positive results in the educational field.

- The researcher benefited from previous studies in formulating theoretical framework of study, defining concepts, and developing a measure of self-creation.

- Previous studies that focus the effective role of self-creation in improving job quality of social workers dealing with extracurricular school activities groups in social work in general and specialists in social group work, prompting the researcher to conduct that study. 
- The present study focuses on role of self-creation in improving job quality of social workers dealing with extra-curricular school activities groups.

point of view presenting the theoretical categories, ethics of social work profession and method of social group work, previous studies and research, we can determine the problem of study in this question : (what is the role of self-creation in improving job quality of social workers dealing with extra-curricular school activities groups)?

The researcher defined procedural concepts of study as follows:

The concept of effectiveness of self-creation quality of work:

is procedurally defined as the overall degree obtained by the respondent on the creative self-efficiency scale used in this study.

Job quality concept. . Educational institutions have ability of to provide material and moral support to social workers. This support leads to greater responsibility [at work. To provide a better functional work environment, and consider it as one of the effective strategies in promoting competitive excellence.

Extra-curricular school activities groups' concept: such activities are planned and intended outside the classroom and carried out under the supervision and guidance of the school administration, teachers and social workers in their respective fields of specialization. Such activities are practiced through school activity groups (sports, artistic, cultural and social). The social workers trains, guides and follows up students in carrying out tasks in extra-curricular activities to which they join. It aims at engaging students in extra-curricular activities to enhance self-confidence and responsibility.

- Study hypotheses: the current research attempts to test the

- Following hypotheses:

- First hypothesis: the job stress of social workers in special

- Education schools is high.

- Second hypothesis: the quality of work life of social workers in

- Special intellectual education schools is low.

- Third hypothesis: there is a statistically significant relationship

- Between job stress and quality of work life among social workers in

- Special intellectual education schools. 
- Fourth hypothesis: there is a statistically significant relationship

- Between the demographic variables (gender, age, marital status,

- Academic qualification, and years of experience) and the degree of job

- Stress in the study sample.

- Fifth hypothesis: there is a statistically significant relationship

- Between demographic variables (gender, age, marital status, academic

- Qualification, and years of experience) and quality of work life in them

- Sample study

Study hypotheses: the current research attempts to test the Following hypotheses:

First hypothesis: the job stress of social workers in special Education schools is high.

Second hypothesis: the quality of work life of social workers in Special intellectual education schools is low.

Third hypothesis: there is a statistically significant relationship Between job stress and quality of work life among social workers in Special intellectual education schools.

Fourth hypothesis: there is a statistically significant relationship Between the demographic variables (gender, age, marital status, Academic qualification, and years of experience) and the degree of job Stress in the study sample.

Fifth hypothesis: there is a statistically significant relationship

Between demographic variables (gender, age, marital status, academic Qualification, and years of experience) and quality of work life in them

Sample study

Study hypotheses: the current attempts to test the following hypotheses:

First hypothesis: there is a statistically significant relationship between the demographic variables (gender, age, marital status, academic qualification, and years of experience) and level of selfefficiency in the creative thinking of social workers (fluency, flexibility, originality, and details). 
Second [hypothesis: there is a statistically significant relationship between the demographic variables (gender, age, marital status, academic qualification, and years of experience) and of self-efficiency in the creative performance of social workers (education for creativity, preservation of creative personality, communication and promotion of creativity).

Third [hypothesis : there is a statistically significant relationship between the role of self-efficiency in the creative thinking of social workers ( fluency - flexibility - originality and details ) with extracurricular school activities groups.

Fourth hypothesis: there is a statistically significant relationship between the role of self in creative [performance of social workers (education for creativity, preservation of creative personality, communication and promotion of creativity) and improving job quality of social workers dealing with extra-curricular school activities groups.

\section{Methodology}

This study is one of the descriptive studies, which provide researchers with a great deal of information about many social phenomena, which will help to establish more accurate research and experimental designs. Descriptive designs are more specific as they draw attention to the features, characteristics and dimensions of research field and its subject. Therefore, the researcher aims through this descriptive study to determine the role of self-creation in improving job quality of social workers dealing with extra-curricular school activities groups.

Where a social survey is to be applied through a comprehensive survey for all social workers located in preparatory schools in Aswan. The researcher, then after, designed a questionnaire form for social workers in the preparatory stage and included preliminary data on some variables such as (age, gender, academic qualification, years of experience in the education field, the number of training courses in the education field, aspects of benefiting from these courses). The questionnaire also included the "1st dimension". The role of selfefficiency in the creative thinking of social workers ( fluency flexibility - originality and details ) and improving job quality of social workers dealing with extra-curricular school activities groups).the questionnaire also included the " 2 nd dimension" role of 
self in creative [performance of social workers (education for creativity, preservation of creative personality, communication and promotion of creativity) and improving job quality of social workers dealing with extra-curricular school activities groups).

The authenticity of the content of this questionnaire was tested by presenting it to a number of five (5) arbitrators from the social work professors at Helwan University, in order to agree on the wording and the relevance of the questions to the variables, for which data required to be collected. The wording has been modified in addition and deletion. Then the researcher tried this form on a number of ten (10) ten social workers (outside the sample of the study) and then reapplied the form on the same sample after fifteen (15) days of the first application the test results were as follows: the study tool was applied to ninety-nine (99) social workers working in the education field of preparatory school through a comprehensive survey con ducted on the period from $05 / 05 / 2019$ to $15 / 05 / 2019$. The result was as follows.

Table (1) shows the distribution of social workers (subject of study) by gender.

$\mathrm{N}=99$

\begin{tabular}{||l||l||l||l||l||}
\hline Sr. & Gender & Repetition & Percentage & Rank \\
\hline \hline 1 & Male & 27 & $27.27 \%$ & 2 \\
\hline \hline 2 & Female & 72 & $72.73 \%$ & 1 \\
\hline \hline & Total & 99 & $100 \%$ & \\
\hline
\end{tabular}

It is clear from the previous table that most of the study members are social workers in preparatory schools of females by $72.73 \%$, followed by $27.27 \%$ of males.

Table (2) shows the distribution of social workers (subject of study) by social status. $\mathrm{N}=99$

\begin{tabular}{|c|c|c|c|c|}
\hline Sr. & Social Status & Repetition & Percentage & Rank \\
\hline 1 & Single & 18 & $18 \%$ & 2 \\
\hline 2 & Married & 75 & $75 \%$ & 1 \\
\hline 3 & "Detached & 4 & $4 \%$ & 3 \\
\hline 4 & "Widowed & 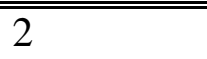 & $2 \%$ & 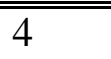 \\
\hline & & \multicolumn{3}{|c|}{$100 \%$} \\
\hline
\end{tabular}

With regard to marital status of the study sample, the results indicated that the percentage of married persons reached $(75.0 \%)$ 


\begin{tabular}{|ll|}
\hline $\begin{array}{l}\text { Egyptian Journal of Social Work (EJSW) } \\
\text { ISSN: 2356-9204 }\end{array}$ & http://ejsw.journals.ekb.eg \\
\hline
\end{tabular}

Table (3) the distribution of social workers (subject of study) in primary schools by age.

\begin{tabular}{||l||l||l||l||l||l||l||l||}
\hline Sr. & Age & Repetition & H & H K & H & Percentage & Rank \\
\hline \hline 1 & Less than 25 & 3 & -2 & -6 & 12 & $3.03 \%$ & 5 \\
\hline \hline 2 & $\begin{array}{l}\text { From 25- } \\
\text { Less than 30 }\end{array}$ & 3 & -1 & -3 & 3 & $3,03 \%$ & 5 \\
\hline \hline 3 & $\begin{array}{l}\text { From 30- } \\
\text { Less than 35 }\end{array}$ & 7 & Zero & Zero & Zero & $7,07 \%$ & 4 \\
\hline \hline 4 & $\begin{array}{l}\text { From 35- } \\
\text { Less than40 }\end{array}$ & 15 & 1 & 15 & 15 & $15,15 \%$ & 3 \\
\hline \hline 5 & $\begin{array}{l}\text { From 40 - } \\
\text { Less than45 }\end{array}$ & 21 & 2 & 42 & 84 & $21,21 \%$ & 2 \\
\hline \hline 3 & $\begin{array}{l}\text { From 45 } \\
\text { and above }\end{array}$ & 50 & 3 & 150 & 450 & $50,51 \%$ & 1 \\
\hline \hline & Total & 99 & & 198 & 564 & $100 \%$ & \\
\hline \hline C: & & & 42,5 & & \\
\hline \hline P & & & 1,51 & & \\
\hline
\end{tabular}

It is clear from the above table that the highest percentage of the study sample of social workers is $(50.51 \%)$ of those aged (45 years and above), followed by (21.21\%) of those aged (from 40 - less than 45), followed by $15.15 \%$ of those aged (35-40), followed by $7107 \%$ of those aged (30-35) and 3.03\% (from 25 less than 30) and (less than $25)$ to confirm their early age against their fewer number .through field interviews with social workers.

Table (4) the distribution of social worker (subject of study) in primary schools by educational qualification

\begin{tabular}{|c|c|c|c|c|}
\hline $\mathbf{S r}$ & Educational Qualification & Repetition & Percentage & Rank \\
\hline 1 & $\begin{array}{l}\text { Intermediate Diploma in Social } \\
\text { Work }\end{array}$ & 43 & 43,43 & 2 \\
\hline 2 & Bachelor of Social Work & 49 & 49,5 & 1 \\
\hline 3 & Bachelor of Arts in Sociology & 3 & 3,03 & 4 \\
\hline 4 & $\begin{array}{l}\text { Postgraduate Diploma in Social } \\
\text { Work }\end{array}$ & 4 & 4,04 & 3 \\
\hline \multicolumn{2}{|c|}{ Total } & 99 & $100 \%$ & \\
\hline
\end{tabular}


It is clear from the previous table that the majority of the sample, subject of research, of social worker with a bachelor's degree in social work by $49.5 \%$, while in the second place those with a diploma in social work by $43.43 \%$, followed by $4.04 \%$ of those with postgraduate diploma in social work, and finally holders of bachelor of arts in sociology (3.03\%).

Table (5) the distribution of those under research from social worker (subject of study) by years of experience in the educational field.

\begin{tabular}{||l||l||l||l||l||l||l||l||}
\hline Sr & $\begin{array}{l}\text { Educational Field } \\
\text { Experience }\end{array}$ & Repetition & H & $\begin{array}{l}\text { H } \\
\text { K }\end{array}$ & $\begin{array}{l}\text { H } \\
\mathbf{k}^{\mathbf{2}}\end{array}$ & Percentage & Rank \\
\hline \hline 1 & Less than 5 years & 8 & - & -16 & 32 & $8,08 \%$ & 4 \\
\hline 2 & $\begin{array}{l}\text { From 5- Less } \\
\text { than 10 }\end{array}$ & 7 & - & -7 & 7 & $7,07 \%$ & 5 \\
\hline 3 & $\begin{array}{l}\text { From -10 Less } \\
\text { than 15 }\end{array}$ & 13 & 0 & 0 & 0 & $13,13 \%$ & 3 \\
\hline \hline 4 & $\begin{array}{l}\text { From -15 Less } \\
\text { than 20 }\end{array}$ & 17 & 1 & 17 & 17 & $17,17 \%$ & 2 \\
\hline 5 & $\begin{array}{l}\text { From 20 and } \\
\text { above }\end{array}$ & 54 & 2 & 108 & 216 & $54,55 \%$ & 1 \\
\hline \hline Total & 99 & 102 & 272 & $100 \%$ & \\
\hline C & 20,15 & & \\
\hline \hline P & $6.5-12$ \\
\hline
\end{tabular}

In the educational field and their percentage reaches (54.55\%) while their experience are more than 20 years and above. They represent the most percentage, and then followed in the second place whose experience ranges between (15 - less than 20) years and they are (17.17\%). In the third place those with ranges between (10 - less than $15)$ years of experience $(13.13 \%)$, followed by fourth place with less than 5 years of experience $(8.08 \%)$. Finally , $7.07 \%$ of those whose experience ranges from 5 to less than 10 years. 


\begin{tabular}{|lc||}
\hline Egyptian Journal of Social Work (EJSW) & http://ejsw.journals.ekb.eg \\
ISSN: 2356-9204 & Vol 12, Issue 1, June 2021 \\
\hline \hline
\end{tabular}

Table (6) the relationship between some demographic variables and level of self-efficiency in the creative thinking of social workers (fluency, flexibility, originality, and details).

\begin{tabular}{|c|c|c|c|c|c|c|}
\hline$\overline{\mathbf{M}}$ & $\begin{array}{l}\text { Demographi } \\
\text { c variable }\end{array}$ & $\begin{array}{l}\text { Coefficien } \\
t \text { used }\end{array}$ & $\begin{array}{l}\text { fluenc } \\
\text { y }\end{array}$ & $\begin{array}{l}\text { Flexibilit } \\
\text { y }\end{array}$ & $\begin{array}{l}\text { originalit } \\
\mathbf{y}\end{array}$ & details \\
\hline 1 & "Gender & $\begin{array}{l}\text { X2 } \\
\text { C.C. }\end{array}$ & 7.312* & 8.701* & "5.951* & $\begin{array}{l}6.701 \\
* *\end{array}$ \\
\hline 2 & $\begin{array}{l}\text { Marital } \\
\text { status }\end{array}$ & $\begin{array}{l}\text { Kendall's } \\
\text { Tau }\end{array}$ & 8.701* & $0.513^{* *}$ & $0.693^{* *}$ & $\begin{array}{l}0.513^{*} \\
*\end{array}$ \\
\hline 3 & Age & $\begin{array}{l}\text { Kendall's } \\
\text { Tau }\end{array}$ & $\begin{array}{l}0.581 * \\
*\end{array}$ & $0.672 * *$ & $0.513^{* *}$ & $\begin{array}{l}0.443^{*} \\
*\end{array}$ \\
\hline 4 & $\begin{array}{l}\text { Academic } \\
\text { qualification }\end{array}$ & $\begin{array}{l}\text { Kendall's } \\
\text { Tau }\end{array}$ & $\begin{array}{l}0.6 \\
89 * *\end{array}$ & $0.443 * *$ & $0.693 * *$ & 7.312* \\
\hline 5 & $\begin{array}{l}\text { Years of } \\
\text { Experience }\end{array}$ & $\begin{array}{l}\text { Kendall's } \\
\text { Tau }\end{array}$ & $\begin{array}{l}0.600 * \\
*\end{array}$ & $0.651^{* *}$ & $0.509^{* *}$ & $\begin{array}{l}0.672 * \\
*\end{array}$ \\
\hline
\end{tabular}

* significant at 0.05

The data in the table above indicates that there is significant relationship between the demographic variables (gender, age, marital status, academic qualification, and years of experience) and level of self-efficiency in the creative thinking of social workers (fluency, flexibility, originality, and details). The value of $7.312=x 2$ in fluency, 8.701 in flexibility, and5.951 in the use of originality and6.701 in the use of details. The strength of this correlation using compatibility coefficient (c.c.) was in the following order: 0.277 , 0.281 , and 0.205 . Statistics showed those females' social workers have creative thinking to improvement of quality of careers with extracurricular school activity groups. Thus the results of this table proved the validity of the first research hypothesis. 


\begin{tabular}{|lc||}
\hline Egyptian Journal of Social Work (EJSW) & http://ejsw.journals.ekb.eg \\
ISSN: 2356-9204 & Vol 12, Issue 1, June 2021 \\
\hline \hline
\end{tabular}

Table (7) the relationship between some demographic variables and self-efficiency in the creative performance of social workers (education for creativity, preservation of creative personality, communication and promotion of creativity).

\begin{tabular}{|l||l||l|l||l|l||}
\hline $\mathbf{M}$ & $\begin{array}{l}\text { Demographic } \\
\text { variable }\end{array}$ & $\begin{array}{l}\text { Coefficient } \\
\text { used }\end{array}$ & $\begin{array}{l}\text { Education } \\
\text { for } \\
\text { creativity }\end{array}$ & $\begin{array}{l}\text { Preservation } \\
\text { of } \\
\text { creative } \\
\text { personality }\end{array}$ & $\begin{array}{l}\text { Promotion } \\
\text { of } \\
\text { creativity }\end{array}$ \\
\hline \hline $\mathbf{1}$ & Gender & $\begin{array}{l}\text { X2 } \\
\text { C.C. }\end{array}$ & $8.701^{*}$ & $7.312^{*}$ & $6.951^{*}$ \\
\hline \hline $\mathbf{2}$ & $\begin{array}{l}\text { Marital } \\
\text { status }\end{array}$ & $\begin{array}{l}\text { Kendall's } \\
\text { Tau }\end{array}$ & $0.651^{* *}$ & $0.689^{* *}$ & $0.871^{* *}$ \\
\hline \hline $\mathbf{3}$ & $\mathbf{A g e}$ & $\begin{array}{l}\text { Kendall's } \\
\text { Tau }\end{array}$ & $0.693^{* *}$ & $0.891^{* *}$ & $0.509^{* *}$ \\
\hline \hline $\mathbf{4}$ & $\begin{array}{l}\text { Academic } \\
\text { qualification }\end{array}$ & $\begin{array}{l}\text { Kendall's } \\
\text { Tau }\end{array}$ & $0.750^{* *}$ & $0.793^{* *}$ & $8.701^{* *}$ \\
\hline $\mathbf{5}$ & $\begin{array}{l}\text { Years of } \\
\text { Experience }\end{array}$ & $\begin{array}{l}\text { Kendall's } \\
\text { Tau }\end{array}$ & $0.878^{* *}$ & $0.772^{* *}$ & $0.651^{* *}$ \\
\hline
\end{tabular}

The data in the table above indicates that there is significant relationship between the demographic variables (gender, age, marital status, academic qualification, and years of experience) and of self-efficiency in the creative performance of social workers (education for creativity, preservation of creative personality, communication and promotion of creativity).. The value of $8.701=\mathrm{x} 2$ in education for creativity, 7.312 in preservation of creative personality and 6.951 in the use of communication and promotion of creativity. The strength of this correlation using compatibility coefficient (c.c.) was in the following order: 0.281, 0.205and 0.288. Statistics showed those females' social workers have creative performance to improvement of job quality with extra-curricular school activities groups. Thus the results of this table proved the validity of the second research hypothesis. 


\begin{tabular}{|lc||}
\hline $\begin{array}{l}\text { Egyptian Journal of Social Work (EJSW) } \\
\text { ISSN: 2356-9204 }\end{array}$ & http://ejsw.journals.ekb.eg \\
\hline
\end{tabular}

Study results: results related to study objectives:

Table (8) no. $1^{\text {st }}$ dimension: role of self-efficiency in the creative thinking of social workers (fluency, flexibility, originality and details) with extra-curricular school activities groups.

\begin{tabular}{|c|c|c|c|c|c|c|c|}
\hline \multirow{2}{*}{ 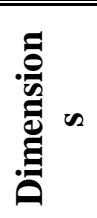 } & \multirow[b]{2}{*}{ Indexes } & \multicolumn{3}{|c|}{ Responses } & \multirow[b]{2}{*}{$\sum_{\bar{E}}^{\bar{E}}$} & \multirow{2}{*}{ 苞 } & \multirow[b]{2}{*}{$\underset{\mathscr{I}}{\stackrel{\mathscr{I}}{\pi}}$} \\
\hline & & $\stackrel{y}{\nu}$ & $\Leftrightarrow$ 点 & $\stackrel{0}{z}$ & & & \\
\hline \multirow{9}{*}{ 总 } & $\begin{array}{l}\text { Helps me find many } \\
\text { possible solutions to my } \\
\text { problems }\end{array}$ & 60 & 30 & 9 & 2.51 & 4.8 & 5 \\
\hline & $\begin{array}{l}\text { Gives me the ability to } \\
\text { think of more than one } \\
\text { answer to the difficult } \\
\text { problems facing me }\end{array}$ & $\overline{770}$ & 16 & 13 & 2.58 & 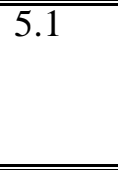 & 3 \\
\hline & $\begin{array}{l}\text { Makes me come up with } \\
\text { a difficult solution to the } \\
\text { problem through } \\
\text { conclusions about it. }\end{array}$ & 59 & 20 & 20 & 2.39 & 4.6 & $\overline{7}$ \\
\hline & $\begin{array}{l}\text { Inspires me with many } \\
\text { ideas for activities }\end{array}$ & $4 \overline{45}$ & 24 & 30 & 2.15 & 4.2 & 8 \\
\hline & $\begin{array}{l}\text { Provides me with the } \\
\text { ability to respond quickly } \\
\text { to questions asked to me }\end{array}$ & 85 & 9 & 5 & 2.81 & $\overline{5.4}$ & 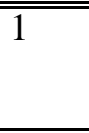 \\
\hline & $\begin{array}{l}\text { Helps me know more } \\
\text { than one resource to get } \\
\text { the potential that an } \\
\text { activity need }\end{array}$ & 66 & 13 & 20 & 2.46 & $\begin{array}{l}4.7 \\
\end{array}$ & 6 \\
\hline & $\begin{array}{l}\text { Helps me express my } \\
\text { thoughts in more than } \\
\text { one way }\end{array}$ & 80 & 9 & 10 & 2.71 & 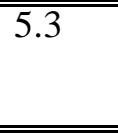 & 2 \\
\hline & $\begin{array}{l}\text { Gives me the ability to } \\
\text { hear others in good } \\
\text { listening }\end{array}$ & 73 & 6 & 20 & 2.54 & 4.9 & 4 \\
\hline & Total dimension & & & & 20.15 & 39.08 & \\
\hline \multirow{2}{*}{ 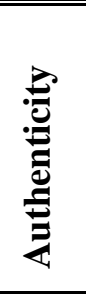 } & $\begin{array}{l}\text { Provides me with the } \\
\text { ability to be the first to } \\
\text { come up with creative } \\
\text { proposals from my peers }\end{array}$ & 66 & 13 & 20 & 2.46 & $\begin{array}{l}4.8 \\
\end{array}$ & ○离 \\
\hline & $\begin{array}{l}\text { Directs me to constantly } \\
\text { reflect on new ideas that } \\
\text { are working on the }\end{array}$ & 85 & $\overline{99}$ & $\overline{5}$ & 2.81 & $\overline{5.4}$ & \\
\hline
\end{tabular}




\begin{tabular}{|lr||}
\hline Egyptian Journal of Social Work (EJSW) & http://ejsw.journals.ekb.eg \\
ISSN: 2356-9204 & Vol 12, Issue 1, June 2021 \\
\hline
\end{tabular}

\begin{tabular}{|c|c|c|c|c|c|c|c|}
\hline \multicolumn{8}{|c|}{\begin{tabular}{l||l} 
success of the school \\
activities program
\end{tabular}} \\
\hline & $\begin{array}{l}\text { Helps me come up with } \\
\text { an unfamiliar new } \\
\text { solution before others } \\
\text { find it }\end{array}$ & 72 & 8 & 19 & 2.54 & 4.9 & 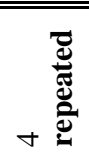 \\
\hline & $\begin{array}{l}\text { Makes me in line with } \\
\text { other in terms of new } \\
\text { ideas }\end{array}$ & $\overline{77}$ & 10 & 12 & 2.66 & $\overline{5.2}$ & 3 \\
\hline & $\begin{array}{l}\text { Gives me the ability to } \\
\text { suggest a set of questions } \\
\text { that stimulate my mental } \\
\text { stimulation. }\end{array}$ & 78 & 11 & 10 & 2.67 & 5.2 & 2 \\
\hline & $\begin{array}{l}\text { Helps me make my } \\
\text { decision } \\
\text { study }\end{array}$ & 74 & $\bar{~} \overline{5}$ & 20 & 2.55 & 4.9 & 4 \\
\hline & $\begin{array}{l}\text { Makes me change the } \\
\text { reality I live more than } \\
\text { the desire to accept it }\end{array}$ & $\overline{55}$ & 15 & 29 & 2.26 & 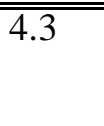 & 8 \\
\hline & $\begin{array}{l}\text { Helps me see things } \\
\text { around me that no one } \\
\text { has noticed before me. }\end{array}$ & 66 & 12 & 21 & 2.54 & 4.8 & 6 \\
\hline & Total dimension & & & & 20.41 & 39.59 & \\
\hline & $\begin{array}{l}\text { Makes me able to come } \\
\text { up with different kinds of } \\
\text { responses, not just } \\
\text { different responses. }\end{array}$ & 70 & 16 & 13 & 2.58 & 4.9 & 4 \\
\hline & $\begin{array}{l}\text { Gives me the ability to } \\
\text { respond to the problem in } \\
\text { different ways, each of } \\
\text { which is unique and } \\
\text { exceptional }\end{array}$ & 66 & 15 & 18 & 2.48 & 4.8 & 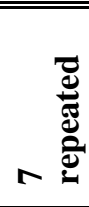 \\
\hline & 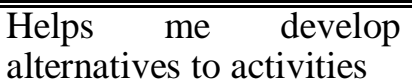 & 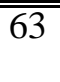 & 20 & 16 & 2.47 & " 4.8 & $\overline{\overline{77}}$ \\
\hline & $\begin{array}{llr}\text { Encourages } & \text { me } & \text { to } \\
\text { introduce a sense } & \text { of } \\
\text { humor while } & \text { doing } \\
\text { activities } & & \\
\end{array}$ & $\overline{72}$ & $\bar{~} 18$ & 9 & 2.64 & $\overline{c 5.1}$ & 3 \\
\hline & $\begin{array}{l}\text { Gives me the ability to } \\
\text { participate in most } \\
\text { activities }\end{array}$ & 73 & 22 & 4 & 2.69 & $\bar{~} 5.2$ & 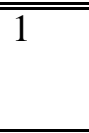 \\
\hline$\frac{D}{\frac{0}{2}}$ & $\begin{array}{l}\text { Helps me to think more } \\
\text { than one pattern about } \\
\text { the problems taking into } \\
\text { account the nature of the } \\
\text { problem. }\end{array}$ & 71 & 11 & 17 & 2.55 & 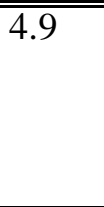 & 5 \\
\hline
\end{tabular}




\begin{tabular}{|lc||}
\hline Egyptian Journal of Social Work (EJSW) & http://ejsw.journals.ekb.eg \\
ISSN: 2356-9204 & Vol 12, Issue 1, June 2021 \\
\hline
\end{tabular}

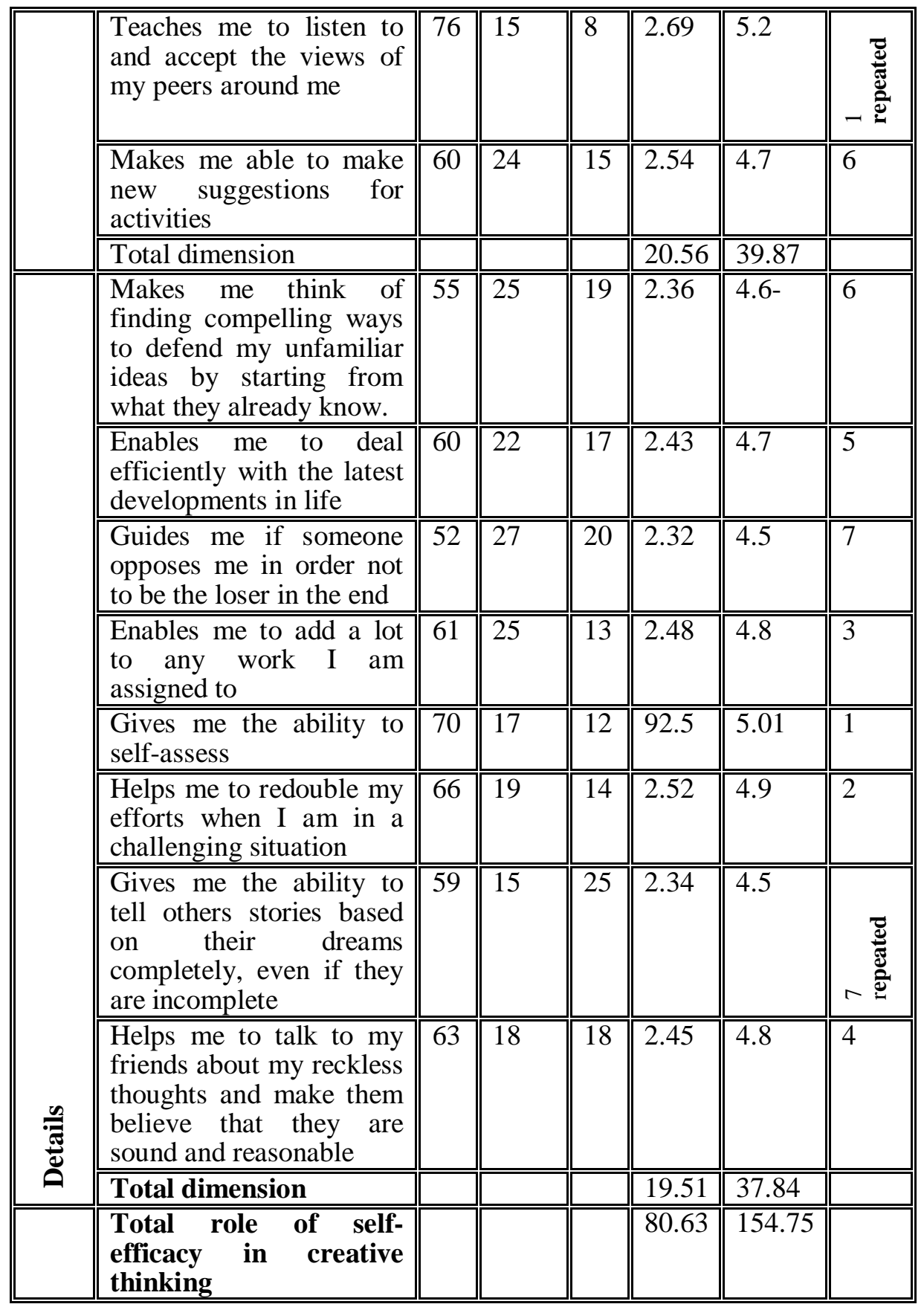

The results of the previous table indicate the role of selfefficiency in the creative thinking of social workers (fluency flexibility - originality and details) with extra-curricular school activities groups. The results of the study indicate that the highest 
responses to fluency in the creative thinking of social worker dealing with extra-curricular school groups (provides me with the ability to respond quickly to questions asked to me), followed by (helps me express my thoughts in more than one way) and finally (inspires me with many ideas for activities). It is also clear from the results that the highest authenticity responses in the creative thinking of social worker dealing with extra-curricular school activity groups (directs me to constantly reflect on new ideas that are working on the success of the school activities program), followed by (gives me the ability to suggest a set of questions that stimulate my mental stimulation) and finally (makes me change the reality i live more than the desire to accept it). The results of the table indicate that the highest responses to flexibility in the creative thinking of social worker dealing with extracurricular school groups (gives me the ability to participate in most activities, teaches me how to listen to and accept the views of my peers around me), and then follow (encourages me to introduce a sense of humor during the activities). Finally, it gives me the ability to respond to the problem in different ways, each of which is unique and exceptional and helps me develop alternatives to activities.

The results of the table indicate that the highest detail responses in the creative thinking of social worker dealing with extracurricular school activities groups (gives me the ability to self-assess), followed by (helps me to redouble my efforts when i am challenged), and finally (gives the ability to tell others stories based on their dreams completely, even if they are incomplete, guides me if someone opposes me in order not to be the loser in the end). The results of the previous table also indicate the role of self-efficacy in the creative thinking of social worker dealing with extra-curricular school activities groups with an arithmetic mean of (22.5) and a weighted weight of (0.81). This may indicate the importance of taking this into account to activate the role of self-efficiency in the creative thinking of social workers (fluency - flexibility - originality and details) with extra-curricular school activities groups.

Table (9) $2^{\text {nd }}$ dimension: the role of self in creative [performance of social workers (education for creativity, preservation of creative personality, communication and promotion of creativity) and improving job quality of social workers dealing with extracurricular school activities groups 


\begin{tabular}{|lr||}
\hline Egyptian Journal of Social Work (EJSW) & http://ejsw.journals.ekb.eg \\
ISSN: 2356-9204 & Vol 12, Issue 1, June 2021 \\
\hline
\end{tabular}

\begin{tabular}{|c|c|c|c|c|c|c|c|}
\hline \multirow[b]{2}{*}{$\stackrel{\Xi}{\stackrel{\Xi}{0}}$} & \multirow[b]{2}{*}{ Indexes } & \multicolumn{3}{|c|}{ Responses } & \multirow[b]{2}{*}{ Mean } & \multirow{2}{*}{$\begin{array}{l}\text { Standard } \\
\text { Deviation }\end{array}$} & \multirow[b]{2}{*}{ ד্তু } \\
\hline & & $\stackrel{\Xi}{\star}$ & $\begin{array}{l}\text { To } \\
\text { Some } \\
\text { Extent }\end{array}$ & Z & & & \\
\hline \multirow{4}{*}{ 㺼 } & $\begin{array}{l}\text { Guides me to understand the thing } \\
\text { that I want to do }\end{array}$ & 55 & 35 & 9 & 2.46 & 4.7 & 2 \\
\hline & $\begin{array}{l}\text { Helps me to start learning to do the } \\
\text { thing even if I face obstacles }\end{array}$ & 58 & 30 & 11 & 2.47 & 4.8 & 1 \\
\hline & $\begin{array}{l}\text { Guides me to learn how to be able to } \\
\text { do new things. }\end{array}$ & 60 & 13 & 26 & 2.34 & 4.5 & 3 \\
\hline & Total dimension & & & & 7.28 & 14.12 & \\
\hline \multirow{4}{*}{ 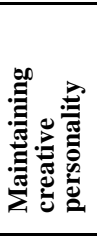 } & $\begin{array}{l}\text { Gives me the ability to be motivated } \\
\text { to come up with new ideas }\end{array}$ & 62 & 17 & 20 & 2.42 & 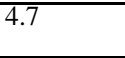 & 1 \\
\hline & $\begin{array}{l}\text { Helps me enjoy coming up with new } \\
\text { ideas after seeing others' ideas }\end{array}$ & $\overline{45}$ & 37 & 17 & 2.28 & 4.4 & 3 \\
\hline & $\begin{array}{l}\text { Direct me to keep my questions } \\
\text { about some things even if I have } \\
\text { been working for years or decades }\end{array}$ & 58 & 14 & 27 & 2.31 & 4.5 & 2 \\
\hline & Total dimension & & & & 7.02 & 13.61 & \\
\hline \multirow{3}{*}{ ن } & $\begin{array}{l}\text { Guides me to create the unusual } \\
\text { things that will appeal to others }\end{array}$ & 59 & 19 & 21 & 2.84 & 0.79 & $\overline{\overline{3}}$ \\
\hline & $\begin{array}{l}\text { Helps me to find listeners who can } \\
\text { easily convey new ideas to others in } \\
\text { the society }\end{array}$ & 56 & 30 & 13 & 2.43 & 0.80 & 2 \\
\hline & $\begin{array}{l}\text { Gives me the ability to communicate } \\
\text { with others to convince them that } \\
\text { what I have done is the best }\end{array}$ & 63 & 22 & 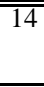 & 2.49 & 0.82 & 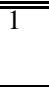 \\
\hline & Total dimension & & & & 7.31 & 14.18 & \\
\hline & $\begin{array}{l}\text { Total role of self-efficacy in creative } \\
\text { performance }\end{array}$ & & & & 21.64 & 41.98 & \\
\hline
\end{tabular}

The results of the previous table indicate the role of self in creative [performance of social workers (education for creativity, preservation of creative personality, communication and promotion of creativity) and improving job quality of social workers dealing with extra-curricular school activities groups as a goal of the study. The results of the study indicate that the highest responses to education in the creative performance of social workers dealing with extracurricular school activities groups (helps me to start learning to do the thing even if $i$ face obstacles), followed by (guides me to understand the thing that $\mathrm{i}$ want to do) and finally (guides me to learn how to be able to do new things) it is also clear from the results that the highest responses to the preservation of creative personality in the creative performance of social workers working with extra-curricular school groups (gives me the ability to be motivated to come up with new ideas), and then followed (direct me to keep my questions about some things even if $i$ have been working for years or decades) and finally (helps me enjoy coming up with new ideas after seeing others' ideas). The results of the table indicate that the highest responses to communication and promotion of creativity in the creative performance of social workers dealing with extra-curricular school 
activities groups (gives me the ability to communicate with others to convince them that what $i$ have done is the best), and then followed (helps me to find listeners who can easily convey new ideas to others in the society), and finally (guides me to create the unusual things that will appeal to others). The results of the previous table also indicate the role of self-efficiency in the creative performance of social workers dealing with extra-curricular school activities groups with an arithmetic mean of (2.39) and a weighted weight of (0.71).this may indicate the importance of taking this into account to activate role of self in creative [performance of social workers (education for creativity, preservation of creative personality, communication and promotion of creativity) and improving job quality of social workers dealing with extra-curricular school activities groups.

\section{Discussion:}

The study identified responses to self-efficacy in the creative thinking of social workers dealing with extra-curricular school activities groups and the highest responses to the fluency dimension in the creative thinking of social workers working with extra-curricular school groups (provides me with the ability to respond quickly to questions asked to me), the highest responses to authenticity in the creative thinking of social workers dealing with extra-curricular school activities groups (directs me to constantly reflect on new ideas that are working on the success of the school activities program), the responses to the flexibility in creative thinking of social workers dealing with extra-curricular school activities groups (gives me the ability to participate in most activities, teaches me how to listen to and accept the views of my peers around me), and then finally the highest responses to detail in the creative thinking of social workers dealing with activity groups extra-curricular schools (gives me the ability to self-assess).the study also identified responses to self-efficacy in the creative performance of social workers dealing with extra-curricular school activities groups, that the highest responses to education in the creative performance of social workers dealing with extra-curricular school activities groups (helps me to start learning to do the thing even if $\mathrm{i}$ face obstacles) the highest responses to maintain the creative personality of the creative performance of social workers working with extra-curricular school activity groups (gives me the ability to be motivated to come up with new ideas), the highest responses for 
communication and promotion of creativity in the creative performance of social workers working with extra-curricular school groups (gives me the ability to communicate with others to convince them that what $\mathrm{i}$ have done is the best). On point views previous studies of ibrahim (1992), emphasized the importance of conducting further studies on social performance of social workers working in all fields to address problems resulting from inadequate gob performance. Abulnasr's study (1999) focused on the professional development of social workers in educational field and aimed to identify methods of professional self-development. Abdulhamid's study (2003) confirmed that the job performance of social workers needs to be continuously improved and developed. Al-ghamdi (2017), aimed to identify the difficulties of use the student guide for extra-curricular activities to develop social skills for primary school students. The present study highlighted the effectiveness of self-creation (thinking and performance) in improving job quality of social workers dealing with extra-curricular school activities groups.

\section{Conclusion}

- It is necessary to hold training courses on how to activate the creative self of social workers dealing with extra-curricular activities groups.

- It is necessary to open online discussion forums between social workers on this subject matter.

- It is necessary to adopt guidance programs on the effectiveness of creative self.

- It is necessary to have simulation models for social workers dealing with extra-curricular groups of creative thinking and performance.

- It is necessary to hold workshops on how to activate the creative self of social workers dealing with extra-curricular activities groups.

- A guidance program regarding the way of working with groups to activate the creative self of social workers working in the educational field.

\section{Study limitation:}

- Difficulty of administrative procedures to accept the application of the study in the institution.

- Lack of knowledge related to the subject of study.

- Difficulty of in designing the measuring tool. 


\section{References}

Abdul Hamid, Y. M., (2003). The relationship between using training

Program and achieving professional development for social Workers in university cities, a Research Published in the $16^{\text {th }}$ Scientific Conference, Helwan University, Faculty of Social Work.

Abou El Nasr, M. M., (1999). Development of professional social Workers in educational field from the perspective of society Organization. Journal of the Faculty of Arts. Helwan University: Faculty of Social Work.

Abbott, D. (2010). Constructing a creative self-efficacy inventory: A Mixed methods inquiry. Unpublished doctoral thesis, Nebraska University, USA.

Ahmed, M. AR., (2016). A proposed program for using extraCurricular school activities to support volunteer work among Preparatory school students from the perspective of group Work. Aswan University: Faculty of Social Work.

Ahmed , N. I., (1992). Assessment of social performance of Social workers working with school groups, a Research Published in the Journal of Social Work and Humanities Studies. Cairo, Egyptian Society of Social Workers.

Ahmed, M. SH.,et al (1999), Supervision and Assessment in Working with Groups, Cairo: Nour El Eman Center.

Al-Gendy, K. M., et al (2004). Professional practice processes In working with groups, Cairo: University Book Publishing and Distribution Center.

Al-Ghamdi, N. BA., (2017) .Obstacles of using student guide for Extra-curricular activities in development of social skills For primary school students, a research Published in he Journal of Social Work and Humanities Studies .Helwan University, Faculty of Social Work P (43), C (10).

Bandura A., (2007). Much ado over a faulty conception of perceived Self-efficacy grounded in faulty experimentation, journal of Social and clinical psychology, 26 (2).

Brockhus S., (2014). The influence of creative self-efficacy on Creative performance. Design 2014. Dubrovnik - Croatia.

Daley, A., \& Leahy, J . (2003). Self-perception ns and participation In extra-curricular physical activities . The Physical Educator.

Dawood , E. H.,(2006). Professional development of social workers In leadership development center in light of total quality 
Management, A Research published in the $9^{\text {th }}$ Scientific

Conference, Helwan University, Faculty of Social Work.

Hassan, H. AL.,(2015). Introduction to work with groups. Amman:

Dar Al-Massira Publishing.

Manchaa S. A., \& Ahmad , A.( 2016) . Co-curricular activities and

Its effect on social skills. International conference on education

And regional development. "Cross-cultural education for

Sustainable regional development "at: Bandung, Indonesia.

Marey, H.,(2005), requirements of developing professional

Performance of social workers working in society development

Associations, a research published in the 16th Annual Scientific

Conference . Fayoum University, Faculty of Social Work, vol III.

NASW. (1990). Standards for social work personnel practice,

U.S: District of Columbia.

Openshaw , L., (2008). The role and function of the school social

Worker. Guilford Publications.

Ohly S., et al (2017) . Developing students' creative self-efficacy

Based on design-thinking: evaluation of an elective

University course, in psychology learning and teaching

, vol. 16(1) 125-132 sagepub.co.uk/ journals Permissions .nav

DOI :10.1177/14757257166817 journals.sagepub.com/home/plat

Shehata, M. M.,(2012), Training needs of social workers working

With individual cases of medical field, a research published

At the 25th international conference, Helwan University:

Faculty of Social Work, $9^{\text {th }}$ vol .Humanities,

Selim, M . [[M., (2011). Evaluation of Extra-curricular Activity Programs

In Light of Comprehensive Educational Evaluation, a research

Published in the Journal of Social Work and Humanities

Studies, Helwan University, Faculty of Social Work, P (30), C (11).

Suleiman, A. El., (1999), Future minds and strategies for gifted

Education creativity development, Riyadh, Golden Page Library.

Shehata , H., (1998). Curriculum between theory and practice,Cairo

, Arab Book House.

Sunday A., A., (2010). The relationship between students'

Participation in school based extracurricular activities and

Their achievement in physics. International Journal of

Science and Technology Education Research Vol. 1(6),

November Available on line http :// www. Academic journals. org/jster,issn,2141- 6559 @2010 academic journals.

Susan Stone (2015). "School social work in the united states: current

Evidence and future directions". Arbor, 191 (771): 
A 201. Doi: http://dx.doi.org/10.3989/arbor.2015.771n1003.

Tierney, P., \& Farmer, S. M. (2002). Creative self-efficacy: its

Potential antecedents and relationship to creative performance. Academy of Management Journal,45, 1137-1148.Brockhus et $\mathrm{Al}$ (2014). The influence of creative self-efficacy on creative Performance . Design 2014. Dubrovnik - Croatia.

Ul Saqib , N ., et all ( 2018). Effects of extracurricular activities on Students . Effects of extra-curricular activities on students. A Department of Electrical Engineering College of Electrical and Mechanical Engineering National University of Sciences and Technology. 